\title{
WAYS OF STABILIZING THE COLOR OF VEGETABLE RAW MATERIAL DURING ITS PROCESSING
}

\author{
A. Dubinina, T. Sherbakova, Yu. Khatskevich, S. Lenert, A. Borysova \\ Kharkiv State University of Food Technology and Trade
}

\begin{tabular}{|c|c|}
\hline Key & \multirow{10}{*}{$\begin{array}{l}\text { The chemical structure of natural dyes (chlorophylls, carote- } \\
\text { noids and substances of phenolic nature) is considered in } \\
\text { this study. Literature data on the existing methods of } \\
\text { stabilizing the color of vegetable raw materials during their } \\
\text { processing into food products is reviewed. General ways for } \\
\text { preventing the oxidation of pigment substances of vegetable } \\
\text { raw materials and preserving natural color of fruits and } \\
\text { vegetables are analyzed. The authors made the conclusion } \\
\text { about the urgency of further searching for the new methods } \\
\text { of stabilizing plant pigments during the processing of fruits } \\
\text { and vegetables, which will be more effective and safe. }\end{array}$} \\
\hline Chlorophylls & \\
\hline Carotenoids & \\
\hline Lycopene & \\
\hline Xanthophylls & \\
\hline Lutein & \\
\hline Phenylpropa & \\
\hline onoids & \\
\hline & \\
\hline $\begin{array}{l}\text { Received in r } \\
07.06 .2017\end{array}$ & \\
\hline
\end{tabular}

Accepted 18.06.2017

Corresponding author:

A. Dubinina

E-mail:

npnuht@ukr.net

DOI: $10.24263 / 2225-2924-2017-23-4-20$

\section{СПОСОБИ СТАБІЛІЗАЦІЇ КОЛЬОРУ РОСЛИННОЇ СИРОВИНИ ПІД ЧАС ІІЇ ПЕРЕРОБКИ}

\author{
А.А. Дубініна, Т.В. Щербакова, Ю.М. Хацкевич, С.О. Ленерт, А.А. Борисова \\ Харківський державний університет харчування та торгівлі
}

У статті розглянуто хімічну будову природних барвників - хлорофілів, каротиноїдів і речовин фенольної природи. Наведено огляд літературних даних про існуючі способи стабілізації кольору сировини рослинного походження під час ї̈ переробки в продукти харчування. Проаналізовано загальні шляхи запобігання окисленню пігментних речовин рослинної сировини та збереження натурального кольору плодів і овочів. Зроблено висновок про актуальність подальшого пошуку нових методів стабілізаиії рослинних пігментів під час переробки фруктів та овочів, які були б більш ефективними і безпечними.

Ключові слова: хлорофіли, каротиноїди, лікопін, ксантофіли, лютеїн, фенілпропаноїди, флавоноїди.

Постановка проблеми. Колір є першою ознакою в товарознавчій оцінці, за якою характеризується якість харчового продукту. Він вказує на сенсорні 
властивості, отже на придатність продукту до споживання. Однак у процесі переробки сировини під дією різних факторів відбувається незворотна зміна кольору. Ці процеси мають достатньо складний характер.

Аналіз існуючих технологій показав, що для запобігання руйнування рослинних пігментів і стабілізації кольору сировини розроблена велика кількість способів. Однак необхідно зазначити, що наведені способи не мають універсального характеру i, зазвичай, не враховують особливості технологічної обробки сировини. Тому вивчення процесів, що призводять до зміни кольороутворюючих речовин під час технологічної переробки, а також визначення способів стабілізації кольору є актуальними питаннями, оскільки ці перетворення впливають на формування якості та споживчі властивості продукту.

Аналіз останніх досліджень і публікацій. Колір рослинної сировини обумовлений наявністю природних барвників - хлорофілів, каротиноїдів і речовин фенольної природи. Перші два відносяться до ліпоїдів, оскільки нерозчинні у воді, а тільки у жирах і органічних розчинниках. Фенольні речовини — водорозчинні пігменти [1].

Колір хлорофілвміщуючої рослинної сировини формується за рахунок якісного і кількісного складу пігментного комплексу. В рослинах загальний вміст хлорофілу складає $0,008 \ldots 0,8 \%$ на сиру масу. Листя соняшника накопичують до $0,16 \%$, дуба - 0,25\%, клена - 0,45\%. У листових овочах загальний вміст пігменту становить 7...15 мг \%. Досліджено, що листя петрушки містять 4,5..6,0 мг\% хлорофілу, кропу - 7,1 ..8 8.5 мг\%. Вміст хлорофілу $(a+b)$ у салаті-латуку складає $3,4 \ldots 4,5$ мг \%, у зеленому солодкому перці $3,3 \ldots 4,9$ мг\%, у зеленому горошку - 17,85...23,11 мг\% хлорофілу $a$ та 2,73...3,95 мг\% хлорофілу $b[2,3-6]$.

Зелений пігмент вищих рослин складається 3 двох сполук - хлорофілу $a$ i $b$. Молекули хлорофілів мають спільну будову — гідрофільне порфіринове кільце з іоном $\mathrm{Mg}^{2+}$ у центрі, що координаційно пов'язаний з атомами азоту, i ліпофільний залишок високомолекулярного ненасиченого спирту фітолу. У результаті ункціонального аналізу виявлена наявність у хлорофілі $a$ метильної групи, у хлорофілі $b$ - альдегідної. Таким чином, молекула хлорофілу фітольним кінцем - «хвостом» - зв'язана 3 ліпідним прошарком мембран хлоропластів, а порфіриновим кільцем - «головою» - звернена в сторону органели [8-10].

Забарвлення рослин, що містять хлорофіл, пов'язане 3 наявністю сполученої системи подвійних зв'язків у порфіриновому кільці, яка дає змогу поглинати видиме світло. Зелений колір обумовлений тим, що хлорофіл поглинає червоне світло (максимум поглинання при 655 нм) і синє світло (максимум поглинання при 430 нм) і відбиває зелене світло [11; 12].

Хлорофіл $а$ добре розчиняється в ефірі, етиловому спирті, ацетоні, бензолі, хлороформі; він малорозчинний у петролейному ефірі; нерозчинний у воді (утворює колоїдні розчини). Спиртові розчини мають синьо-зелений колір i темно-червону флуоресценцію. Хлорофіл $b$ виявляє аналогічні властивості [8].

Численними дослідженнями встановлено, що хлорофіли $a$ i $b$ легко руйнуються під впливом світла, кисню повітря, тепла, кислот і лугів. У розчині, 
навіть при кімнатній температурі, хлорофіли піддаються ізомеризації до близьких за структурою сполук, які є епімерами власне хлорофілів [13-15]. Під дією мінеральних кислот, навіть дуже слабких, відбувається відщеплення $\mathrm{Mg}^{2}$ від хлорофілів $a$ і $b$ та утворення відповідних похідних - феофітинів $a$ i $b$. Сильні мінеральні кислоти викликають утворення феофорбідів $a$ i $b$, які характеризуються відсутністю в молекулі високомолекулярного спирту фітону [8; 9; $16-18]$.

Накопичені до теперішнього часу дані свідчать про те, що хлорофіл не тільки впливає на споживні властивості продуктів харчування своїм кольором, але і підвищує харчову цінність, вносить вклад у такі характеристики, як фізіологічна цінність, лікувально-профілактичні властивості продукту, оскільки має біологічно активну дію. За результатами експериментів ряд авторів вказують на можливу участь хлорофілу в утворенні гемоглобіну, еритроцитів і лейкоцитів в організмі людини і тварин [19-21]. Є дані про регенеративну та антисептичну дію препаратів хлорофілу, особливо при лікуванні опіків 2-го і 3-го ступенів, інфікованих виразок гомілки різного походження - варикозне розширення вен, тромбофлебіт, злоякісних новотворів. Гарні результати отримані при використанні хлорофілів у лікуванні екзем, світлових дерматозів, контактних і токсичних дерматитів, дерматофітозів, псоріазу [19; 20; 22; 23].

Використання препаратів хлорофілу (наприклад, $\mathrm{Cu}-$ хлорофіліну) у стоматології при лікуванні стоматитів, піорреї, пародонтозу, гінгивиту, кровотечі ясен, а також при виробництві зубних паст, пов'язане не тільки 3 високими бактерицидними властивостями, але і з наявністю дезодоруючої дії, заснованої, мабуть, на хімічному зв'язуванні та окисленні речовин [24].

Багатьма авторами вказується на перспективність використання біологічно активних препаратів хлорофілу для зниження реакції організму в процесах загоєння чужорідних тканин, для лікування шлунково-кишкових захворювань, при невритах і невралгії потрійного нерва тощо. Такі препарати не викликають алергічних реакцій, тому можуть бути використані при тривалому лікуванні [25-28].

Удосконалення методів комплексної переробки рослинної сировини для одержання зеленого пігменту і його похідних буде сприяти більш широкому їхньому застосуванню не тільки у фармацевтичній, парфумерній, але й у харчовій промисловості. Проте важливо під час переробки зберегти природний зелений колір, тобто запобігти перетворенням хлорофілу.

Каротиноїди знайдені у всіх зелених тканинах рослин. Співвідношення хлорофілів і каротиноїдів у хлоропластах становить у середньому 3:1. Однак під дією різних факторів хлоропласти перетворюються в хромопласти, забарвлення яких змінюється від жовтого до червоного в залежності від складу речовин [7; 28-30].

До каротиноїдів відноситься велика група пігментів. Дотепер виділено близько 70 видів каротиноїдів, визначено близько 500 структур цих сполук, однак описані формули й властивості лише 58 з них [8; 31].

3 хімічної точки зору практично всі каротиноїди відносяться до терпеноїдів - тетратерпенів, сполук, вуглецевий кістяк яких складається з восьми $\mathrm{C}_{5}$-ізопренових фрагментів. Основна структура молекули симетрична й побу- 
дована 3 двох тотожних половин. Кожна половина складається 3 чотирьох ізопренових залишків, пов'язаних способом «голова» до «хвоста». Завдяки такій будові каротиноїди поглинають частину спектра білого світла й забарвлюють плоди у кольори від жовтого до жовтогарячого та червоного.

Найпоширенішим жовтим пігментом є каротин. Зелені листя рослин містять 200...300 мг\% каротину на кілограм сирої речовини. У великих кількостях виділено його з листя і коренеплодів моркви, люцерни (Medicago L.), кропиви (Urtica), шпинату (Spinacia Z.), зі шкірочки червоного перцю, з плодів абрикоса (Armeniac S.), горобини (Sorbus Z), обліпихи (Hippophae L), томатів, банана (Musca P.), дині (Melo S.S. M.Roem). Каротин виявлений також у квітках нарциса, кульбаби (Taraxa W.), буквиці (Betonica L.) [24; 29; 32-37]. У рослинній сировин каротин існує у вигляді ізомерів: найпоширенішими 3 них $\epsilon \alpha-, \beta-, \gamma$-каротини. Вони відрізняються неоднаковим розташуванням подвійних зв'язків і хімічних властивостей. Листя рослин містять $\beta$-каротину у кількості 200...700 мг на 1 г сухої маси [38-41].

$\alpha$-Каротин зустрічається відносно рідко. У $68 \%$ видів рослин, таких як шпинат, кропива, артишок, ячмінь, його вміст коливається від 0,2\% до 35\% всієї каротинової фракції [19; 24; 42; 43]. Інші ізомери каротину $(\gamma-, \delta-, \xi-, \chi-)$ виявлені у різних сполуках у складі пігментів окремих видів рослин [36; 44 48].

Іншим каротиноїдом, що є головним компонентом пігментного комплексу поряд 3 каротином і має таку ж сумарну формулу та ізопреновий кістяк, $\epsilon$ лікопін. На відміну від каротину, молекула лікопіну має лінійну будову, симетричне розташування, 13 кон'югованих зв'язків. Це основний барвник червоних томатів, він зустрічається також у шипшині, кавунах, абрикосах, брусниці [29; 49-52].

До кисневміщуючих каротиноїдів відносяться ксантофіли. Вони відрізняються від каротинів тим, що їхня молекула замість однієї або декількох метиленових груп містять гідрокси-группу або карбоніл. У рослинних тканинах iз ксантофілів переважає лютеїн, що за структурою дуже близький до $\alpha$-каротину, але на відміну від нього атом водню заміщений гідрокси-групою [8; 31$]$.

Лютеїн - найпоширеніший пігмент у хлоропластах поряд $3 \beta$-каротином, він виділений з листів каштану кінського, кропиви пекучої, шпинату, із квіток конюшини червоної, квіток соняшника. У середньому вміст його в листі становить $60 \ldots 65$ мг\% $[29 ; 33 ; 35 ; 53 ; 54 ; 55]$.

Окислення кисневмісних похідних каротинів призводить до утворення епокси-каротиноїдів. Цей процес $\epsilon$ важливим у тканинах, де відбуваються процеси фотосинтезу, тому що утворені епокси-форми захищають хлорофіл від фотоокислення. До епокси-форм відноситься віолаксантин, що ідентифікований у пігментному комплексі й відповідає за колір пелюстків жовтої матері-і-мачухи, яскраво-жовтих апельсинів, мандаринів [24; 56].

Криптоксантин $є$ кисневмісним похідним $\beta$-каротину та має властивості провітаміну А. Він наявний у листках рослин у невеликій кількості, шкірці плодів мандаринів, маїсі, червоному перці. Його вміст складає приблизно 30\% всіх каротиноїдів ягід фізаліса, з яких він був уперше виділений [29; 57-61]. 
Зеаксантин $є$ основним барвником зерен кукурудзи, плодів обліпихи, виділений із плодів японської хурми (Diospyros K.). У плодах персиків вміст його становить $3,8 \%$, в абрикосах досить мало - у середньому $0,7 \%$ [29; 31$]$.

Інші ксантофіли досить специфічні для окремих видів рослин. Так, родоксантин $є$ основним ксантофілом плодів тису; у плодах деяких видів шипшини ідентифікований рубіксантин; із червоного перцю виділені речовини капсорубін і капсоксантин [54; 60; 61].

Таким чином, каротиноїдний комплекс кожного виду рослини являє собою суміш основних каротиноїдів, включаючи ізомери і їх похідні у різних співвідношеннях. В абрикосах основним каротиноїдом є $\beta$-каротин $(50 \ldots 80 \%$ від загальної кількості); вміст $\gamma$-каротину становить 3,9 ; $\xi$-каротину $-0,6$; $\alpha$-каротину $-0,2$; лікопіну $-1,0$; із ксантофілів наявні: лютеїн $-2,1$, криптоксантин - 3,1, зеаксантин - 0,7\% від загальної кількості [29]. При дослідженні пігментного комплексу моркви була встановлена наявність двох ізомерів каротину: $\alpha$-каротину і $\beta$-каротину. При цьому, за одними даними вміст $\alpha$-каротину становить від 5 до $10 \%$ всіх каротинів моркви; за іншими даними $19,5 \ldots 42,2 \%$. Окрім $\alpha$-, $\beta$-ізомерів, у моркві міститься також $\gamma$-каротин $(0,1 \%$ від загальної кількості каротиноїдів); $\delta$-каротин, $\xi$-каротин і лікопін загальною кількістю $0,1 \%$. Вміст ксантофілів - 5\% від загального вмісту. У гарбузі містяться $\alpha-, \beta-, \gamma$-каротини, віолаксантин, флавоксантин. Загальна кількість складає від 9 мг\% до 50 мг\% у перерахунку на суху речовину [33; 45; 62].

Використовуючи в їжу рослини, що містять каротиноїдний комплекс пігментів, людина підвищує захисні функції організму проти несприятливого впливу навколишнього середовища. Біологічне значення каротиноїдів для живого організму спочатку розглядалося 3 погляду їх А-вітамінної активності. Сьогодні відомо, що не тільки $\beta$-каротин, але й інші каротини мають антиканцерогенну активність, володіють радіопротекторними та імуностимулюючими властивостями [26; 63; 64]. Каротиноїди використовують при лікуванні хвороби Паркінсона, атеросклерозу, діабету, бронхіальної астми, при різних формах дерматитів. Підвищився інтерес до каротиноїдів як до антиракових речовин [65]. Вони можуть виконувати роль оксигеназ, що придушують дію токсинів багатьох організмів [9].

Отже, каротиноїди відіграють важливу роль у організмі людини і $є$ важливим компонентом іiі раціону харчування.

Поряд із хлорофілами й каротиноїдами поширення в природі одержали поліфеноли. Це велика група органічних сполук, що відрізняються за хімічною будовою, але мають деякі загальні ознаки. Характерними рисами фенольних сполук $є$ : легке окислення з утворенням високореактивних проміжних продуктів типу семихіонних радикалів або орто-хінонів; здатність до взаємодії з білками за рахунок утворення водневих зв'язків, а також схильність до комплексоутворення з іонами металів.

3 урахуванням основного вуглеводного кістяка, фенольні сполуки можна розділити на групи [9]:

- найпростіші фенольні сполуки (сполуки $\mathrm{C}_{6}$-ряду);

- сполуки $\mathrm{C}_{6}-\mathrm{C}_{1}$-ряду (оксибензойні кислоти і їхні похідні), 
- сполуки $\mathrm{C}_{6}-\mathrm{C}_{3}$-ряду (фенілпропаноїди - оксикоричні кислоти і їхні похідні, оксикумарини),

- флавоноїди (сполуки $\mathrm{C}_{6}-\mathrm{C}_{3}-\mathrm{C}_{6}$-ряду).

Р-вітамінна активність властива багатьом флавоноїдам. Саме із цієї причини в літературі часто фігурує термін «біофлавоноїди». При цьому максимальною активністю володіють представники найбільш відновлених класів флавоноїдів, тобто катехіни й флаван-3, 4-діоли, хоча на практиці через більшу доступність i стабільність у лікувальних і профілактичних цілях найчастіше використовують флавоноли, особливо рутин. Однак катехіни, крім Р-вітамінної активності, володіють гепатопротекторними властивостями, використання яких знайшло широке застосування у фармацевтичній галузі країн світу [26].

Розмаїтість природних флавоноїдів досягається за рахунок наявності асиметричних атомів вуглецю в гетероциклі (у катехінів, флаванонів, флаванонолів, лейкоантоціанидінів), за рахунок реакцій гідроксилювання, метилірування, ацилірування ароматичних ядер. Крім розмаїтості агліконів, велика чисельність сполук пояснюється значною розмаїтістю цукрових залишків. Так, наприклад, для одного лише пеларгонідину відомо понад 20 різних глюкозидних похідних [66-68].

Антоціани можуть бути розбиті на 21 підклас залежно від характеру цукрового залишку. 3 монозидів антоціанової природи найпоширенішими $\epsilon$ глюкозиди, галактозиди; рамнозиди й арабінозиди зустрічаються рідше [69].

Антоціани, на відміну від хлорофілу, є непластидними пігментами. У клітині вони, вочевидь, існують у вигляді солей з органічними кислотами. При нейтральних значеннях $\mathrm{pH}$ антоціани утворюють нестійкі безбарвні псевдооснови, у лужних середовищах — мають досить нестійкі хиноїдні структури.

Антоціани є похідними катіона флавілію - 2-фенілбензопирилію. Виділені з рослин чисті антоціани зазвичай мають червоне або фіолетово-червоне забарвлення. Взаємозв'язок між складом антоціанів і забарвленням шкірочки винограду був досліджений японськими вченими у 30 сортах винограду. За складом антоціанів сорти винограду можна розділити на 5 типів: сорти, що містять в основному цианідин; сорти, що містять більше $50 \%$ неонідину; сорти, що містять більше $60 \%$ дельфінідину; сорти, що містять в основному енидин; сорти, що містять в основному мальвідин [70; 71].

Антоціани містяться у рослинах винятково у формі гликозидів, у яких залишки цукрів зв'язані із забарвленим агліконом. Найчастіше в природі зустрічаються глікозиди цианідину, дельфінідину, пеларгонідину; при цьому глікозиди ціанідину зустрічаються у $69 \%$ фруктів і 50\% квіток, що містять антоціани [72-74].

Зі збільшенням кількості фенольних гідроксильних груп колір плодів змінюється від рожевого, через помаранчево-червоний до синього, як це спостерігається в ряді цианідин $\rightarrow$ мальвідин $\rightarrow$ дельфінідин. Метилірування гідроксильної групи змінюе колір у цьому ряді у зворотному напрямку. Крім числа гідроксильних груп, на колір впливає й положення цих груп у молекулі [8; 75].

Канадські вчені встановили, що м'якоть яблук з темно-червоною шкірочкою й червоною м'якоттю містить цианідин-3-галактозид, цианідин-3-глюкозид, 
цианідин-3-арабінозид, катехін, флаван-3-он та ін. У цілому вміст антоціанів у яблуках коливається у межах 90...100 мг/кг [76; 77].

Антоціанів у ягодах червоної й чорної смородини міститься в середньому 100 мг\% і 1500 мг\% відповідно, причому у різних сортах вміст коливається в широкому діапазоні. Досліджено, що у сортах червоної смородини Lonkheer, Vantet's i Latran вміст антоціанів становить більше 400 мг/кг; у сорті Deutuan 284 мг/кг. У чорній смородині сорту Otdo міститься до 2500 мг/кг антоціанів, у сорті $\mathrm{B}_{0} 539$ - більше 4000 мг/кг. За забарвлення ягід червоної смородини відповідає аглюкон цианідин; ягід чорної смородини - цианідин і дельфінідин [78].

Забарвлення багатьох сортів вишні обумовлене наявністю антоціану керацианіну, у якому одна молекула глюкози й одна молекула рамнози пов'язані з агликоном цианідином. Фенольні сполуки сливи представлені різними групами: у сортах Угорка й Ренклод переважають олігомерні форми катехінів (132-156 мг\% у шкірочці й $163-220$ мг\% - у м'якоті); вільних катехінів 39 і 19 мг\% відповідно, лейкоантоціанів - 206-356 мг\%. Барвником сливи $\epsilon$ пруніціанин - глюкорамнозид цианідину; міститься також у невеликій кількості кверцетин (менше 15\% від загальної кількості) [78].

Аналіз літературних даних дає змогу зробити висновок про різноманіття природних барвників, які, перебуваючи у різному співвідношенні, формують забарвлення рослинної сировини й продуктів іiї переробки. Здебільшого це нестійкі сполуки, які легко змінюються під впливом багатьох факторів, що приводить до втрати натурального кольору плодів і овочів. Саме тому аналіз літературних даних про існуючі способи стабілізації кольору рослинної сировини під час ії переробки $є$ достатньо актуальним.

Метою дослідження $\epsilon$ аналіз літературних даних про існуючі способи стабілізації природного кольору продуктів переробки овочів і фруктів.

Викладення основного матеріалу дослідження. Існують різні способи запобігання трансформації хлорофілу, які базуються на використанні спеціальних режимів обробки, тобто температурі, тривалості ії дії, додаванні стабілізаторів, антиокислювачів, а також комбіновані методи.

При заморожуванні для деяких плодів та овочів рекомендують попереднє бланшування, оскільки активність окислювально-відновних ферментів може частково зберігатися у цих умовах, що призводить до появи неприємного присмаку і запаху при розморожуванні і подальшому застосуванні $[2 ; 6 ; 79]$.

J.W. Heaton запропоновано спосіб переробки зелених овочів з метою збереження зеленого кольору, що досягається застосуванням тільки одноразового нагрівання. Бланшування рекомендується проводити при високих темпеpatypax $\left(120 \ldots 185^{\circ} \mathrm{C}\right)$ протягом часу, необхідного для знищення мікроорганізмів та інактивації ферментів [80].

J.A. Steet встановлено оптимальні режими бланшування зеленого горошку. Це дозволило зберегти текстуру, колір, вітамін С. Руйнування хлорофілу склало $20 . . .35 \%$ [81].

Встановлено позитивний вплив низьких температур на збереженість пігментів. Хлорофіл практично не руйнується протягом 9 місяців у листяній 
селері при зберіганні за умов мінус $28^{\circ} \mathrm{C}$, а зберігання листяних овочів при температурі плюс $1^{\circ} \mathrm{C}$ призводить до мінімального руйнування аскорбінової кислоти та хлорофілу. Відмічено негативний вплив на стабільність хлорофілу коливання температури в процесі зберігання [22].

Дослідження вмісту хлорофілу в заморожених зелених бобах були проведені бразильськими вченими. Встановлено, що при зберіганні за температур мінус $18^{\circ} \mathrm{C}$, мінус $2^{\circ} \mathrm{C}$, мінус $24^{\circ} \mathrm{C}$ протягом 30 місяців вміст хлорофілу в бобах не змінився [82].

J.W. Heaton провів дослідження впливу різних технологічних факторів на вміст хлорофілів а і $b$ та їх похідних у качанчиках брюссельської капусти. Качанчики бланшували за температури плюс $100^{\circ} \mathrm{C}$ протягом 4,5 хвилини та швидко охолоджували. Зразки заморожували у рідкому азоті та рідкому вуглекислому газі до температури мінус $20^{\circ} \mathrm{C}$ впродовж 2 годин. Всі зразки зберігали за температури мінус $20^{\circ} \mathrm{C}$ протягом 58 тижнів. У свіжих зразках капусти сорту Zanebot встановлена кількість хлорофілу $a-4,36$ мг\%, хлорофілу $b-2,41$ мг\%; хлорофіліду $a-0,67$ мг\% та хлорофіліду $b-0,43$ мг\%. Після бланшування в зразках капусти знайдено хлорофілу $a-4,16$ мг\%, хлорофілу $b-2,14$ мг \%; хлорофіліду а $-0,76$ мг\%, хлорофіліду $b-0,43$ мг\%. У процесі зберігання заморожених зразків спостерігалося зниження вмісту пігментів. Краще пігменти збереглися в зразках, заморожених у вуглекислому газі: після 58 тижнів зберігання знайдено хлорофілу $a-3,56$ мг\%, хлорофілу $b-0,210$ мг\%; хлорофіліду $a-0,71$ мг\%, хлорофіліду $b-0,41$ мг\% [83].

М. Сапо аналізував вміст хлорофілів і феофітинів у плодах ківі після обробки й зберігання методами АОАC та Vernon. При використанні методу Vernon кислотність плодової маси зразків перед екстракцією пігменту доводили до значення $\mathrm{pH}$ 7,5 та кип'ятили протягом 5 хвилин. Плодове пюре зберігалося за температури мінус $18^{\circ} \mathrm{C}$ протягом 1 ...68 діб. Відмічено значний вміст хлорофілу в пюре після 36 діб зберігання [48].

У літературі наведено спосіб виготовлення паст із свіжої кропиви за методом механохімічної активації, який дає змогу збільшити вміст хлорофілу порівняно з методом мацерації у спиртовій пасті на $11 \%$, масляній - на $31 \%$, спиртово-масляній - на $14 \%$. Отриманий продукт - однорідна, тонкодисперсна маса яскраво-зеленого кольору з характерним смаком і запахом кропиви. Використання цих паст як натуральних біодобавок і барвників в інші продукти позитивно впливає на їх харчову цінність і надає виробам рівномірного забарвлення, достатньо стійкого при темперуванні [53].

Запропоновано спосіб виробництва консервів із зеленого горошку, при якому як добавки використовуються $\mathrm{NaCl}, \mathrm{CaCl}_{2}$ або інша водорозчинна органічна харчова сіль кальцію. Це сприяє отриманню більш темного забарвлення горошку і запобігає втраті біологічно активних речовин [84].

Японськими і американськими вченими було встановлено, що обробка шматочків цукіні $0,5 \%$ водним розчином хлориду кальцію запобігає потемнінню тканин при зберіганні за температури $0^{\circ} \mathrm{C}$ [85].

Для підвищення стабільності хлорофілу здійснюють заміну іону $\mathrm{Mg}^{2+}$ на $\mathrm{Cu}^{2+}$. Таким чином отримують водорозчинний $\mathrm{Cu}$-комплекс хлорофіліну, що 
$€$ продуктом неповного гідролізу хлорофілу. Отримана структура має стійкий яскраво-зелений колір та високу біологічну активність. Відмічено, що препарати, які містять Сu-комплекс хлорофіліну, не тільки не токсичні, але й у деяких випадках знижують дію токсинів і алергенів. Визначено, що $\mathrm{Cu}$-похідні хлорофілу застосовуються у харчовій промисловості Японії та США. Також відомий спосіб отримання стійкого барвника зеленого кольору на основі похідних хлорофілу - хлорофіліну натрію [19].

На стабільності хлорофілу в лужному середовищі грунтується спосіб отримання барвника зі шпинату. Автори способу за допомогою додавання розчину $\mathrm{NaOH}$ концентрацією 2 г/л до подрібненої рослинної сировини переводять у розчинний стан не тільки альбуміни, глобуліни, проламіни, глютеліни, але й хлорофіл $a$ і $b$ та каротиноїди. Отриманий барвник містить $25 \%$ сухих речовин і має $\mathrm{pH} 3,7$, що регулюється додаванням оцту [86].

Н.В. Кацерікова для отримання барвника зеленого кольору рекомендує спосіб видалення хлорофілу з рослинної сировини за допомогою екстракції вуглеводнями $з$ додаванням спирту або ацетону [25].

Запропоновано спосіб, що запобігає зміні кольору капусти завдяки введенню рисової олії і токоферолів. Спосіб підвищує стійкість хлорофілів при різних $\mathrm{pH}$, дії світла і температури [83].

Аналіз досліджень Л.М. Пилипенко показав, що стабілізуюча дія на хлорофіл притаманна полісахаридам (крохмаль), солям, органічним кислотам, жиророзчинним речовинам (каротиноїди, токофероли). При підвищенні руйнування хлорофілу за наявності мінеральної кислоти на 9,1..10,8\% спостерігається стабілізація за наявності солей органічних кислот — цитрату на 5,3\% і 5,9\%, аскорбату — на 10,9\% і 11,8\% для екстракту і нативних хлорофілів відповідно. Експериментально встановлено позитивний вплив катіонів на протекторний захист: $\mathrm{Na}^{+}$сприяє збереженню до $2,9 \%$ і 4,8\% хлорофілу, $\mathrm{Mg}^{2+}-7,4 \%$ i $9,0 \%$ для екстракту і продукту відповідно. Результати досліджень дали змогу розробити способи запобігання руйнування пігментів листових овочів під час виробництва за допомогою добавок $\mathrm{MgCl}_{2}(0,1 \ldots 0,5 \%)$, аскорбінової кислоти $(0,05 \ldots 0,15 \%)$, рослинної олії $(0,01 \ldots 0,3 \%)$, а також подрібнення продуктів в ізотонічному розчині $\mathrm{NaCl}[19]$.

У науковій літературі досить докладно наводяться способи попередження руйнування каротиноїдного комплексу фруктово-овочевої сировини. Відомо, що каротиноїди у вільному стані, тобто не зв'язані у комплекси з білками або ліпідами, достатньо лабільні. Протекторними властивостями стосовно окислення цих речовин володіють, як вказує Т. Кудрицька, гідрохінон, пірогалол, сантонін і його водорозчинні солі, ділудін тощо [29].

Крім вищезазначених методів для захисту $\beta$-каротину від руйнування, бразильські вчені пропонують використовувати цитрати, тартрати, фосфати $i$ кальцій, оскільки вони сповільнювали руйнування $\beta$-каротину темно-зелених листових овочів [36].

Вченими запропонований спосіб отримання натурального барвника 3 морквяного соку. 3 метою стабілізації кольору у сік вводиться яблучний пектин. Отриманий морквяно-пектиновий порошок виявляє стійкість забарвлення при нагріванні до температури плюс $85^{\circ} \mathrm{C}$ у діапазоні $\mathrm{pH} 2 \ldots 10$. Для 
виробництва морквяного соку, що зберігає вихідний колір і аромат моркви, запропоновано під час подрібнення моркви обприскування водним розчином лимонної кислоти або лимонного соку у кількості $0,05 \ldots . .0,5 \%$ від маси моркви і нагрівання до $85^{\circ} \mathrm{C}$ для інактивації ферментів. Спосіб забезпечує ефективний захист пігментів готового соку [34].

У літературі наводиться спосіб стабілізації каротинового барвника за допомогою обробки сировини (моркви, гарбуза, персиків, абрикосів) $\mathrm{NaCl}$, цукровим сиропом, оцтовою, лимонною, аскорбіновою, молочною, сорбіновою кислотами, бензоатами або їх композиціями. Отримані результати показали високу ефективність обробки і можливість збільшення термінів зберігання овочевих напівфабрикатів [87].

Аналіз методів стабілізації фенольних сполук і попередження потемніння харчових продуктів дав змогу визначити, що головними 3 них $є$ регуляція технологічних параметрів обробки, використання антиоксидантів окислення флавоноїдів та інгібіторів ферментативної активності. Крім того, одним із шляхів стабілізації $є$ використання натуральних пігментів, вилучених 3 рослинної сировини і продуктів життєдіяльності мікроорганізмів. Використання натуральних барвників дає можливість не тільки отримати задану кольорову гаму продуктів, але й збагатити їх нутрієнтами - вітамінами, глікозидами, органічними кислотами, мікроелементами [24; 25; 88].

3 метою запобігання потемнінню та втраті антоціанів ягодами аронії авторами був запропонований паровий метод бланшування. При цьому температура пари не перевищувала $90 . . .95^{\circ} \mathrm{C}$, термін обробки - 5 хв. Як стверджують автори, це призводить до максимального збереження флавоноїдів та кольору ягід, однак конкретних даних не наведено [89].

Традиційні способи попередньої обробки (подрібнення) яблук викликають потемніння та помутніння соку вже через $5 . .10$ хвилин. Тому в якості ефективного рішення цієї проблеми використовують обробку цілих плодів або подрібненої маси за допомогою НВЧ-енергії, наприклад з частотою 1900...2900 МГц протягом 2,0..3,5 хв. Отриманий сік світлий, прозорий, без брунатного відтінку. Визначена оптична густина складає $0,3 \ldots 0,35(0,8 \ldots 0,9$ у соку, отриманому після подрібнення) [90].

Дослідження впливу високих температур на якість соку з яблук сорту Гренні Сміт дали змогу авторам розробити технологію, яка поєднує в одну стадію подрібнення й обробку парою за температури $65 . . .70^{\circ} \mathrm{C}$ плодів протягом 15...20 сек. Крім окислювальних ферментів така обробка інактивує пектиназу, яка регулює процес агломерації колоїдів у соку [91].

Дослідження процесів стерилізації консервів, проведені Б. Флауменбаумом і С. Танчевим, дали змогу встановити математичну модель оцінки впливу цього процесу на антоціани плодів і ягід та отримати таблично-аналітичний метод розрахунку ефекту стерилізації і деградації антоціанів [92].

Ю.Г. Скориковою визначені загальні шляхи запобігання окисленню флавоноїдів і збереження натурального кольору плодів і ягід:

- використання видів і сортів плодів 3 високим вмістом антоціанів, флавонолів і низьким вмістом флавонів, а також ураховування співвідношення різних форм флавоноїдів; 
- інактивація ферментів під час руйнування рослинної тканини при обробці плодів;

- роз'єднання компонентів реакції окислення (в основному проведенням процесів обробки плодів в умовах, що запобігають наявності кисню повітря);

- використання стабілізаторів;

- додавання натуральних антоціанових барвників або синтетичних антоціанів, подібних натуральним.

Як стабілізатор натурального кольору пропонуються цистеїн; поліфосфати у поєднанні з сульфітами та лимонною кислотою; амінокислоти, а також рибофлавін, рутин, тіосечовина, пропілгалат. Додавання цистеїну у яблучний сік у кількості 4...24\% сприяло запобіганню процесу потемніння. Ефективність використання цього препарата для стабілізації кольору, обумовленого антоціанами, була достатньо низькою [93].

Для запобігання зміни кольору пігменту червонокачанної капусти японські вчені пропонують додавати рутин i/aбо кверцетин, а також фітин i/aбо фітинову кислоту [30].

Відомо, що найбільш універсальним інгібітором ферментативного і неферментативного потемніння рослинної сировини під час іiї переробки $є \mathrm{SO}_{2}$. Особливостями цього реагенту порівняно з іншими є його висока відновна властивість, завдяки чому він запобігає оксидаційним змінам у рослинних продуктах, таким як руйнування аскорбінової кислоти та ферментативне потемніння фенольних сполук. У той же час він руйнує вітамін $\mathrm{B}_{1}$ [53].

Сульфітація використовується при виробництві багатьох харчових продуктів та фруктових напівфабрикатів - пюре, пульпи, соку, плодів, залитих соком або водою. Абрикоси, груші, агрус, виноград, смородину, яблука заливають робочим розчином 3 концентрацією $1,5 \%$. До пюре яблучного, сливового додають (у \% до маси продукту) $0,1 \ldots 0,18 \% \mathrm{SO}_{2}$, ягідного - $0,1 \ldots 0,15 \%$; для обробки свіжої вишні, чорної смородини -0,20\%; сливи - $0,15 \%$. Концентрація сульфітної кислоти, що є достатньою для запобігання потемніння соків, знаходиться у межах $0,05 \ldots 0,15 \%$ залежно від виду та хімічного складу соку. Також з цією метою використовують суміш, яка складається 3 $\mathrm{Na}_{2} \mathrm{SO}_{3}(10 \ldots 90 \%)$ i $\mathrm{NH}_{4} \mathrm{Cl}[90,94]$.

Однак, сульфітація рослинних продуктів негативно впливає не тільки на смак, але й на організм людини і використовувати їх можна тільки після десульфітації.

Іншим реагентом 3 аналогічною дією $є$ аскорбінова кислота. Встановлено, що синтетична кислота, що вводиться у продукт, частково піддається руйнуванню з утворенням темнозабарвлених сполук. Ступінь руйнування залежить від умов перебігу оксидаційних процесів та наявності розчиненого кисню. Для зберігання натурального кольору соків 3 м'якоттю із яблук, персиків, слив жовтого забарвлення рекомендується додавати цієї кислоти у межах $0,03 \ldots 0,05 \%$. У той же час відомо, що використання аскорбінової кислоти для стабілізації кольору консервів з полуниці або інших плодів та ягід, що мають інтенсивне антоціанове забарвлення, не можливе [78; 95].

Важливе значення має стабілізація окислювальних процесів при отриманні натуральних барвників з рослинної сировини або з відходів інших вироб- 
ництв. 3 цією метою використовують аскорбінову, лимонну або винну кислоти. Барвник 3 вичавок винограду сорту Сапераві отримують екстракцією вказаними кислотами у вигляді $1 \%$ спиртового розчину. Вміст сухих речовин у концентрованому барвнику складає $30 . . .40 \%$; він дає стійке забарвлення харчовим продуктам у діапазоні $\mathrm{pH} 2,8 \ldots 4,5$ [53].

3 метою отримання продукції високої якості розроблена технологія виготовлення варення з попереднім заморожуванням сировини. Для запобігання потемнінню плодів перед заморожуванням сировину витримували у різних розчинах: протягом 1 години у $2 \%$ розчині суміші $\mathrm{NaCl}$ та лимонної кислоти; протягом $40 \mathrm{xв}$ - у $5 \%$ розчині $\mathrm{NaCl}$; протягом $30 \mathrm{xв}-$ у розчині, що містив $7 \%$ аскорбінової кислоти і $0,1 \% \mathrm{NaCl}$. При температурі плюс $70^{\circ} \mathrm{C}$ проводилося короткочасне витримування (протягом 5 хв) у розчині, що містив по $0,2 \%$ лимонної кислоти і харчового гліцерину, при тиску 66,6 кПа. Найкращі результати запобігання потемнінню плодів під час відтаювання отримані при обробці яблук у розчині, що містив по 0,2\% лимонної кислоти і гліцерину, для абрикосів - розчином що містить 7\% аскорбінової кислоти і $0,1 \% \mathrm{NaCl}$ протягом 1 години [96].

У літературі наведені результати досліджень впливу на потемніння абрикосів таких технологічних процесів, як подрібнення плодів у вакуумі або в замороженому стані, додавання до пюре добавок (1\% лимонної кислоти; $0,1 \%$ кверцетину та аскорбінової кислоти; $10 \%, 20 \%$ та 50\% сахарози), купажування з іншими видами сировини, що містять природні стабілізатори та антиоксиданти. Аналіз результатів показує, що використання вакуумування або заморожування мінімально впливає на зміну кольору продукту - на $20,0 \%$ і 21,4\% відповідно; добавка аскорбінової кислоти — на $31 \%$, добавка кверцетину — на $32,2 \%$, лимонної кислоти - на $33,3 \%$ до вихідного значення. Максимальне потемніння спостерігалося у зразках з додаванням сахарози $-57 . . .71 \%$ [97].

Дослідження, проведені вченими ХДУХТ, з метою визначення впливу різних факторів на динаміку руйнування флавоноїдів, дали визначити раціональні режими обробки різних видів плодово-ягідної сировини, а також ефективність використання добавок для стабілізації ії пігментів. Встановлено, що $\mathrm{NaCl}$ ефективно захищає лейкоантоціани плодів сливи - ï вміст після обробки складав 293 мг\% (без обробки 165 мг\%), вміст катехінів збільшився 3 40 до 58\%, антоціанів - 3 64,5 до 70,5\%. Ще більший ефект виявився при використанні водних витяжок з коріандру і червоного перцю: ця композиція стабілізує усі фракції поліфенольних речовин до 67,7\% [98].

Були визначені раціональні способи обробки сировини 3 метою максимального збереження флавоноїдів: для яблук - обробка розчином, що містить $4 \ldots 6 \%$ лимонної кислоти, $0,5 \ldots 1,0 \% \mathrm{NaCl}$ протягом 20 хв при температурі плюс $10{ }^{\circ} \mathrm{C}$; для сливи та вишні - витримування з сухим $\mathrm{NaCl}$ протягом 20 хв при температурі плюс $20^{\circ} \mathrm{C}$; для абрикосів - обробка $3 \ldots 5 \%$ розчином $\mathrm{NaCl}$ протягом $10 \ldots 15$ хв. Результати досліджень дали змогу розробити технології отримання фруктових фаршів - продуктів 3 високими споживчими властивостями [99]. 
Результати дослідження із збереження і відновлення червоних пігментів соку буряку за допомогою антиоксидантів показали, що аскорбінова та ізоаскорбінова кислоти є протекторами пігментів при $\mathrm{pH} 3,8$. При $\mathrm{pH}$ 6,2 більш ефективними виявилися метафосфорна і глюконова кислоти [53].

В.М. Болотовим та іншими авторами проведені експерименти 3 хімічної модифікації структури натуральних антоціанових барвників. За результатами досліджень розроблено спосіб отримання стійкого антоціанового барвника 3 вичавок плодів аронії, що відрізняється стабільністю червоного кольору у водно-спиртових розчинах з $\mathrm{pH}$ 7,6 та термостійкістю у 2,2 раза вищою ніж у природного барвника [100].

Для отримання порошкоподібного харчового барвника 3 вичавок чорної смородини як антиоксидант використали лимонну кислоту, завдяки чому виготовлений барвник мав темно-червоний колір, стабільний протягом $3 \ldots$ 4 місяців зберігання при температурі не вище плюс $20^{\circ} \mathrm{C}$ [100].

Г.К. Гафізовим та ін. запропонований спосіб підвищення стабільності вихідного кольору гранатового соку при зберіганні, який полягає в тому, що натуральний освітлений або неосвітлений гранатовий сік обробляють сумішшю глюкози і лимонної кислоти у співвідношенні компонентів 1:0,020:0,003. Сік зберігає природний колір протягом часу, що визначений у нормативній документації. Кольорність отриманого соку становить $\mathrm{D}_{525}=0,175$ [101].

Відомий спосіб запобігання потемнінню картоплі після іiї обсмажування, що включає обробку бланшованої промитої картоплі речовиною, яка містить іони кальцію - для утворення комплексних сполук з хлорогеновою кислотою на поверхні картоплі (1\% розчин хлориду кальцію). Другий компонент запобігає окисленню заліза, яке наявне на поверхні картоплі (наприклад, $0,15 \ldots 1 \%$ розчин ацетату кальцію). Час такої обробки коливається від 30 до 60 секунд. Запропонований також спосіб обробки картоплі у розчині, що містить $0,05 \%$ сульфітуючого агента $\left(\mathrm{NaHSO}_{3}\right)$ i $0,45 \%$ L-цистеїну протягом 10 хв. Оброблені таким чином шматочки картоплі мають після зберігання протягом 7 діб при температурі плюс 4,4 C колір свіжої картоплі на відміну від зразків, що оброблялися розчином тільки одного компоненту [102].

У [3] вивчалася можливість інгибірування процесу потемніння салатулатуку. Процес покоричневіння вивчався на зразках качанів салату, які промивали та просочували розчинами інгібіторів: аскорбінової кислоти, цистеїну, лимонної кислоти, глюконової кислоти, резорцинолу, рутину, катехолу, гідрохінону, а також лимонним соком та оцтом. Далі зразки зберігали при температурі плюс $2^{\circ} \mathrm{C}$ протягом 7 діб з подальшою зміною температурного режиму до плюс $13^{\circ} \mathrm{C}$ протягом 3 діб з щоденними вимірюваннями забарвлення зразків. За отриманими даними автори зробили висновки, що цистеїн $(0,1$ г/л), резорцинол $(0,1$ г/л), етилендіамінтетраоцтова (5 г/л) та лимонна (100 г/л) кислоти, різні концентрації оцтової кислоти $(10,50,100$ г/л) та оцет ефективно запобігають покоричневінню. Найбільш сприйнятливими у використанні автори вважають оцтову кислоту та оцет.

S. Guyot, N. Marnet та ін. використовували для інактивації ферментів яблук реакційну суміш, що складалася 3 аскорбінової кислоти (редуцент), 
лимонної кислоти (підкислювач) та хлориду натрію для обробки яблук. При цьому ефект інгібірування склав $90 \ldots 100 \%$. У той же час обробка яблук розчином, що містив аскорбінову та лимонну кислоти і хлорид кальцію, була малоефективною [77].

Інгібірування ферментативного покоричневіння рослинних продуктів i напоїв такими реагентами, як аскорбінова кислота (1\%) та хлорид кальцію $(0,1 \%)$, дає змогу інактивувати поліфенолоксидазу та зберегти колір і мікробіологічні показники в охолоджених продуктах (температура нижча плюс $4^{\circ} \mathrm{C}$ ). Також для цих продуктів використовують хелатоутворюючі сполуки, підкислювачі, комплексоутворюючі агенти - мальтодекстрини, циклодекстрини. Також досліджено використання похідних резорцинолу, наприклад, 4-гексилрезорцинолу, для запобігання ферментативного потемніння плодоовочевої сировини. Використання цього реагенту в поєднанні 3 аскорбіновою кислотою $(0,02 \%$ та $0,5 \%$ відповідно) дає змогу запобігти мікробіологічному псуванню, деструкції тканин, потемнінню маси [102].

У літературі йдеться про те, що поєднання високого тиску (50...500 МПа) 3 тепловою обробкою за температури плюс $20 \ldots 60^{\circ} \mathrm{C}$ під час переробки плодів зрілих томатів на томатне пюре дає змогу знизити активність таких ферментів, як поліфенолоксидаза, пероксидаза та пектинметилестераза. При тиску 150 МПа і температурі плюс $30^{\circ} \mathrm{C}$ активність пектинметилестерази знижується на 32,5\%; при тиску 350 МПа і температурі плюс $20^{\circ} \mathrm{C}$ на $25 \%$ знижується активність пероксидази; при тиску 200 МПа і температурі плюс $20^{\circ}$ С активність поліфенолоксидази знижується на 10\% [103].

Утім дослідники V.R.A. Gomes, D.A. Ledward зазначають, що поліфенолоксидаза, виділена з плодів або овочів, по-різному реагує на обробку високим тиском: повна інактивація ферменту, виділеного 3 грибів, відбувалася при обробці протягом 5 хв під тиском 800 МПа. В той же час при цих умовах фермент, виділений із зразків картоплі, батату, яблук, зберігає в середньому до $10 . .20 \%$ своєї вихідної активності [104].

\section{Висновки}

Аналіз літератури дає змогу зробити висновок, що головними способами для запобігання руйнування рослинних пігментів, а, відповідно, і кольору готового продукту є:

- вдосконалення технологічних режимів переробки рослинної сировини (температура, тиск, тривалість обробки);

- використання добавок як рослинного походження, так і синтетичних речовин, що запобігають неферментативним процесам окислення пігментів;

- використання інгібіторів ферментативного окислення пігментів у рослинній сировині;

- поліпшення кольору за рахунок регуляції $\mathrm{pH}$ продукту за допомогою кислот, підлужуючих агентів.

Однак використання багатьох перелічених речовин $є$ дуже небезпечним для здоров'я людини. Деякі способи складні технічно і потребують переобладнання виробництв, ефективність багатьох способів викликає сумніви. Враховуючи вищесказане, актуальним є пошук нових методів стабілізації 
рослинних пігментів під час переробки фруктів та овочів, які були б більш ефективними і безпечними.

\section{Література}

1. Дудкин М.С. Новые продукты питания / М.С. Дудкин, Л.Ф. Щелкунов. - Москва : МАИК, Наука, 1998. — 304.

2. Пилипенко А.Н. Научные основы технологии консервированных пищевых продуктов из листовых овощей: дисс... доктора техн. наук. / А.Н. Пилипенко. — Одесса, 1994. — 267 с.

3. Castaner M. Inhibition of browning of harvested head lettuce // J. Food Sci. - 1996. Vol. 61, № 2. - P. 314-316.

4. Heaton J.W. Kinetic model for chlorophyll degradation in green tissue //J.Agr. and Food. Chem. - 1996. - 44, № 2. - P. 399-402.

5. Zarebski A. Microfalowe suszenic lisci pietruszki // Przem.Spoz. — 1995. —Vol. 49, № 5. P. $168-169$.

6. Steet J.A. Quatification of color change resulting from pheofitinization and nonenzymatic browning reaction in thermally processed green peas // J.Agr. and Food. Chem. - 1996. Vol. 44, № 6. - P. 153-164.

7. Chen B.H. Studies on the stability of carotenoids in garland chrysanthemum as affected by microwave and conventional heating // J. Food Prot. - 1992. - Vol. 55. - P. 296-300.

8. Бриттон Г. Биохимия природных пигментов./ Под ред. М.Н. Запрометова. - Москва : Мир, 1986. - 422 с.

9. Кретович В.Л. Основы биохимии растений / В.Л. Кретович. - Москва : Высшая школа, 1971. - 278c.

10. Бохинский Р. Современные воззрение в биохимии / Р. Бохинский. - Москва : Мир, 1987. - $543 \mathrm{c}$.

11. Мерзляк М.Н. Пигменты, оптика листа и состояние растений // Соросовский образовательный журнал : Серия Биология. - 1998. - № 4. - С. 19-24.

12. Schwartz S.J. Chlorophylls in foods // CRC Food Sci. Nutr. - 1990. - Vol. 29. - P. 1 - 17.

13. Лосев А.П. Обнаружение в растворах нелигандированной формы хлорофилла и протохлорофилла // Доклады АН БССР. - 1987. — Т. 31, № 2. - С. 131-134.

14. Weerd F.L. Dynamics of p-Carotene-to-Chlorophyll Singlet Energy Transfer in the Core of Photosystem II // J. Phys. Chem. B. - 2003. - Vol 107, № 25. - P. $6214-6220$.

15. Schwartz S.J. Chlorophyll stability during continuous aseptic processing and storage // J. Food Sci. - 1991. - Vol. 56. - P. 1059-1062.

16. Койфман О. И. Сольватация молекул порфирина // Журнал физической химии. 1983. - Т. 57, № 3. - С. 590-594.

17. Мерзляк М.Н. Спектры отражения листьев и плодов при развитии, старении и стрессе // Физиология растений. - 1997. — Т. 44, № 15. - С. $34-37$.

18. Canjura F.L. Separation of chlororyll compound // Z. Food Chem. - 1992. - Vol. 45. P. $129-134$.

19. Пилипенко А.Н. Научные основы технологии консервированных пищевых продуктов из листовых овощей: дисс. ... доктора техн. наук. / А.Н. Пилипенко. - Одесса, 1994. - $267 \mathrm{c}$.

20. Block G. Fruit, vegetables, and cancer prevention: a review of the epidemiological evidence // Nutr. Cancer. - 1992. - Vol. 18. - P. 1-29.

21. Joshipura $K$. The effect of fruit and vegetable intake on risk of coronary heart disease // Ann. Intern. Med. - 2001. - Vol. 134. - P. 1106-1114.

22. Eitenmiller Ronald R. Vitamin analysis for the health and food sciences.2nd Edition. CRC Press, 2002. - 675 p.

23. Ames B. Oxidants, antioxidants, and the degenerative diseases of aging // Proc. Natl. Acad. Sci. - 1993. - Vol. 90. - P. 7915-7922.

24. Лебедева Т.С. Пигменты растительного мира / Т.С. Лебедева, К.М. Сытник. Киев : НД, 1986. - 86 с. 
25. Качерикова Н.В. Натуральные пищевые красители / Н.В. Кацерикова, В.М. Позняковский. - Новосибирск : Экор, 2000. - 60 с.

26. Кретович В.Л. Почему растения лечат / В.Л. Кретович. - Москва, 1989. — 254 с.

27. Ялкут С.М. Профилактическое питание в онкологии / С.М. Ялкут, В.И. Циприян. Москва : ПолиграфТехСервис, 2002. - 67 c.

28. Halliwell $B$. Reactive oxygen species and the central nervous system // J. Neurochem. 1992. - Vol. 59. - P. 1609-1623.

29. Кудрицкая C.E. Каротиноиды плодов и ягод / С.Е. Кудрицкая. - Київ : Вища школа, 1990. - $211 \mathrm{c.}$

30. Delgado-Vargas F. Natural pigments: Carotenoids, anthocyanins, and betalains: Characteristics, biosynthesis, processing, and stability // Crit. Rev. Food Sci. Nutr. — 2000. — Vol. 40. P. 173-179.

31. Гудвин Т. Сравнительная биохимия каротиноидов / Томас Гудвин. - Москва : ИЛ, 1986. - $403 \mathrm{c}$.

32. Abushita A.A. Change in carotenoids and antioxidant vitamins in tomato as a function of varietal and technological factors // J. Agric. Food Chem. - 2000. - Vol. 48. - P. 2075-2083.

33. Sulaeman A. Carotenoid content, physicochemical, and sensory qualities of deep-fried carrot chips as affected by dehydration/rehydration, antioxidant, and fermentation / A. Sulaeman, L. Keeler, S. Taylor //J. Agric. Food Chem. - 2001. - Vol. 49. — P. 3253 - 3260.

34. Marx M. Effects of thermal processing on trans-cis isomerization of p-carotene in carrot juices and carotene-containing preparations // Food Chem. - 2003. - Vol. 83. P. 609-617.

35. Kidmose $U$. Content of carotenoids in commonly consumed Asian vegetables and stability and extractability during frying //J. Food Compos. Anal. — 2006. - Vol. 19.P. 562-570.

36. Godoy H.T. Occurrence of cis isomers of provitamins A in Brazilian vegetables // J. Agric. Food Chem. - 1998. - Vol. 46. - P. 3081-3087.

37. Shi J. Lycopene in tomatoes: chemical and physical propeities affected by food processing // Crit. Rev. Food Sci. Nutr. - 2000. — Vol. 40. - P. 1.

38. Liebler D.C. Antioxidant reactions of carotenoids // Ann. NY Acad. Sci.. - 1993. Vol. 691. - P. 2021-2028.

39. Khachik $F$. Effect of food preparation on qualitative and quantitative distribution of major carotenoid constituents of tomatoes and several green vegetables / F. Khachik, M. Goli // J. Agnc. Food Chem. - 1992. — Vol. 40. - P. 390-399.

40. Landen W.O. Liquid Chromatographic Analysis of all-trans-retinyl palmitate, (3carotene, and vitamin $\mathrm{E}$ in fortified foods and the extraction of encapsulated and onencapsulated retinyl palmitate / W.O. Landen, R.R. Eitenmiller // J. Agric. Food Chem. — 2000. — V.48(9). P. 4003-4008.

41. Hornero-Mendez D. Separation and quantification of the carotenoid pigments in red peppers paprika and oleoresin by reversed-phase HPLC // J. Agric. Food Chem. - 1993. — Vol .41. - P. $1616-1620$.

42. Saleh M.N. Separation and identification of cis-trans carotenoid isomers / M.N. Saleh, B. Tan // J. Agric. Food Chem. - 1991. — Vol. 39. — P. 1438-1443.

43. Minguez-Mosguera M.I. Changes in carotenoid esterification during the fruit ripening of Capsicum annuum. Cv Bola // J. Agric. Food Chem. - 1994. - Vol. 42. — P. 640 - 644.

44. Sanchez-Moreno C. Vitamin C, provitamin A carotenoids, and other carotenoids in highpressurized orange juice during refrigerated storage //J. Agric. Food Chem. - 2003 - Vol. 51 . - P. 647-653.

45. Sant'Ana H.M.P. Carotenoid retention and vitamin A value in carrot (Daucus carota L.) prepared by food service // Food Chem. - 1998. — Vol. 61. — P. 145-151.

46. DellaPenna D. Vitamin synthesis in plants: tocopherols and carotenoids / D. DellaPenna, B.J. Pogson //Annu Rev. Plant Biol— 2006. — Vol. 57. — P. 711—738. 
47. Mercadante A.Z. Carotenoids from yellow passion fruit (Passiflora edulis) // J. Agric. Food Chem. - 1998. - Vol. 46. - P. 4102-4106.

48. Cano M. HPLC separation of chlorophyll and carotenoid pigments of four kiwi fruit cultivars // J. Agric. Food Chem. - 1991. — Vol. 39. - P. 1786-1791.

49. Baysal T. Supercritical CO2 Extraction of P-Carotene and Lycopene from Tomato Paste Waste / T. Baysal, S. Ersus, D. Starmans // J. Agric. Food Chem. - 2000. - Vol. 48(11). P. 5507-5511.

50. Daood H.G. Separation of tomato fruit pigments by TLC and HPLC // Acta Aliment. 1987. - Vol. 16. - P. 339-350.

51. Daood H.G. Antioxidant vitamin content of spice red pepper (paprika) as the one affected by technological and varietal factors // Food Chem. — 1996. — Vol. 55. - P. 365-372.

52. Lin C. H. Stability of carotenoids in tomato juice during storage / C.H. Lin, B.H. Chen // Food Chem. - 2005. - Vol. 90. - P. 837-842.

53. Дудкин М.С. Новые продукты питания / М.С. Дудкин, Л.Ф. Щелкунов. - Москва : МАИК, Наука, 1998. - 304 с.

54. Chandler L.A. HPLC Separation of cis-trans-carotene isomers in fresh and processing fruits and vegetables / L.A. Chandler, S.J. Schwartz // J. Food Sci. — 1987. — Vol. 52. P. 669-672.

55. Chen B.H. Effects of different cooking methods on yield of carotenoids in water convolvulus // J. Food Prot. - 1990. - Vol. 53. - P. 1076-1080.

56. Barbary $O$. Focussed difference testing for the assessment of differences between orange juices made from orange concentrate / O. Barbary, R. Monaka, J. Chan // J Sens Stud. — 1993. Vol. 8. - P. 43-67.

57. Biacs P.A. Carotenoids and carotenoid esters from new cross-cultivars of paprika / P.A. Biacs, H.G. Daood, T.T. Huszka // J. Agric. Food Chem. - 1993. - Vol. 41. P. $1864-1867$.

58. Biacs P.A. Studies on the carotenoid pigments of paprika // J. Agric. Food Chem. 1989. - Vol. 37. - P. 350-353.

59. Markus $F$. Change in the carotenoid and antioxidant content of spice red pepper (paprika) as a function of rippering and some technological factors // J. Agric. Food Chem. 1998. - Vol. 46. - P. 131-1134.

60. Minguez-Mosguera M.I. Effect of processing of paprika on the main carotenes and esterified xanthophylls present in the fresh fruit // J. Agric. Food Chem. - 1993. - Vol. 41. P. $2120-2124$.

61. Hornero-Mendez D. Comparative study of the effect of paprika processing on the carotenoids in peppers of the Bola and Agridulce // J. Agric. Food Chem. - 1994. — Vol. 42. P. $1555-1560$.

62. Chen B.H. Processing and stability of carotenoid powder from carrot pulp waste // J. Agric. Food Chem. - 1998. — Vol. 46. - P. 2312-2318.

63. Карнаухов В.Н. Биологические функции каротиноидов / В. Н. Карнаухов. - Москва : Наука, 1988. - $240 \mathrm{c}$.

64. Лікарські рослини: Енциклопедичний довідник /Відп. ред. А.М. Гродзинський. Київ : 1989. - 115 с.

65. Contestabile A. Antioxidant strategies for neurodegenerative diseases // Expert Opin. Therapeutic Patentis. - 2001. — Vol. 11. - P. 573-585.

66. Запрометов М.Н. Основы биохимии фенольных соединений / М.Н. Запрометов. Москва : Высш. шк., 1974. - 67 с.

67. Запрометов М.Н. Фенольные соединения. Распространение, метаболизм и функции в растениях / М.Н. Запрометов. - Москва : Наука, 1992. — 272 с.

68. Бриттон Г. Биохимия природных пигментов./ Под ред. М.Н. Запрометова. Москва : Мир, 1986. - 422 с.

69. Liu R.H. Health benefits of fruit and vegetables are from additive and synergistic combinations of phytochemicals // Am. J. Clin. Nutr. — 2003. — Vol. 78 (3 Suppl). — P. 517—520. 
70. The Flavonoid / J.B. Harborne, T.J. Mabry, H. Mabry. — London, 1981. — 1204 p. Vinson J.

71. Phenol antioxidant quantity and quality in foods: fruits // J. Agric. Food Chem. - 2001. Vol .49. - P. 5315-5321.

72. Sun J. Antioxidant and antiproliferative activities of common fruits // J. Agric. Food Chem. - 2002. - Vol. 50. - P. 7449-7454.

73. Einbond L.S. Anthocyanin antioxidants from edible fruits // Food Chem. - 2004. Vol. 84. - P. 23-28.

74. Кричковская Л.В. Природные антиоксиданти: биотехнологические, биологические и медицинские аспекты / Л.В. Кричковская, Г.В. Донченко, С.И. Чернышев. - Харьков : Дизайн-проект, 2001. - 378c.

75. Динамика антоцианов в плодах аронии при холодильном хранении / Е.В. Красникова, В.И. Филиппов // Низкотемпературные и пищевые технологии в 21 веке : мат. межд. науч.-практ. конф. : С-Пб, 6-7 июня, 2001. - Санкт-Петербург : Изд-во СПбГУНиПТ, 2001. - 389 с.

76. Renard C. Interactions between apple cell walls and native apple polyphenols' quantification and some consequences // Int. J. Biol. Macromol. - 2001. - Vol. 29. P. $115-125$.

77. Guyot S. Variability of the polyphenolic composition of cider apple (Malus domestica) fruits and juices // J. Agric. Food Chem. - 2003. - Vol. 51. — P. 6240 -6247.

78. Танчев C.C. Антоцианы в плодах и овощах / С.С. Танчев. - Москва : Пищ. Промть, 1980. - $304 \mathrm{c}$.

79. Schwartz S.J. Chlorophylls in foods // CRC Food Sci. Nutr. - 1990. - Vol. 29. - P. 1 - 17.

80. Heaton J.W. Kinetic model for chlorophyll degradation in green tissue // J.Agr. and Food. Chem. - 1996. — 44, № 2. - P.399-402.

81. Steet J.A. Quatification of color change resulting from pheofitinization and nonenzymatic browning reaction in thermally processed green peas // J.Agr. and Food. Chem. - 1996. Vol. 44, № 6. - P. 153-164.

82. Monreal $M$. Influence of critical storage temperatures on degradative pathways of pigments in green beans //J. Agric. Food Chem. - 2000. - V.41. - P.19-24.

83. Heaton J.W. Discolouration of coleslaw caused by chlorophyll degradation // J. Agric. Food Chem. - 1996. - Vol. 44. - P. 395 - 398.

84. Valadez-Blancol $R$. In-line colour monitoring during food extrusion: Sensitivity and correlation with product colour // Food Res. Intl. — 2007. — Vol.40, № 9. — P. 1129—1139.

85. Monzocco L. Review of non-enzymatic browning and antioxidant capacity in processed foods / L. Monzocco, S. Calligaris, D. Mastrocola //Trends in Food Science and Technology 2001. - Vol. 11. - P. 340-346.

86. Delgado-Vargas F. Natural Pigments: Carotenoids, Anthocyanins and Betalains characteristics, biosynthesis, processing and stability // Critical Rev. in Food Sci. and Nutr. 2000. - Vol. 40, № 3. - P. 173-289.

87. Lin C.H. Effects of thermal processing on stability of carotenoids in some fruit and vegetabies //Food Chem. - 2003 - Vol. 88, - P. 1112-1116.

88. Бакулина О.Н. Натуральные красители : К вопросу об улучшении потребительских свойств отечественных продуктов питания // Пищевая промышленность. - 1999. — № 8. C. $46-47$.

89. Saure M.C. External Control of Anthocyanin Formation in Apple // Sci. Hortic. — 1990. Vol. 42. - P. 181-218.

90. Merzlyak M.N. Apple Flavonols during prossessing / M. N. Merzlyak, A.E. Solovchenko, A.J. Smagin // J. Plant Physiol. — 2005. — Vol. 162. — P. 151-160.

91. Genovese D.B. Color and cloud stabilization in cloudy apple juice by steam heating during crushing / D.B. Genovese, M. Elustondo, J.E. Lozano // J. Food Sci. - 1997. — V. 62, № 6. - P.1171-1175.

92. Флауменбаум Б.Л. Основы консервирования пищевых продуктов / Б.Л. Флауменбаум, С.С. Танчев. - Москва : Агропромиздат, 1986. — 494 с. 
93. Скорикова Ю.Г. Полифенольный состав плодов и овощей и его изменение в процессе консервирования / Ю.Г. Скорикова. - Краснодар : КПИ, 1988. — 69 с.

94. Hutchings $J$. Colour, appearance, expectations and the food industry// Trends in Food Sci. and Technol. - 2002. - Vol. 11. - P. 340-346.

95. Марк А.Т. Биохимия консервирования плодов и овощей / А.Т. Марх. - Москва : Пищ. пром-ть, 1977. - 340 с.

96. Баранова Н.В. Разработка технологии производства плодово-ягодных смесей из замороженного сырья: автореф. дис. на соискание науч. степени канд. техн. наук: 05.18.16 / Ялта, 1996. - 2000. - 21 c.

97. Луканин А.С. Комплексная переработка плодово-ягодного сырья // Пищевая промышленность. - 1992. - № 1. - С. 31-33.

98. А.с. 1660669 А1 СССР, МКИ5 А 23 L 1/06. Способ производства вишнёвого или сливового фарша / М.И. Беляев, А.А. Дубинина, Л.П. Малюк, В.И. Анохина (СССР). № 4727491/13; заявл. 07.08.1989; опубл. 07.07.1991, Бюл. № 25. - 6 с.

99. Новое в технологии переработки плодового сырья / Л.П. Малюк, Л.Н. Пилипенко, А.А. Дубинина, С.М. Шамян. - Харьков : Изд. Харьк. Ин-та общественного питания, 1995. - $106 \mathrm{c}$.

100. Болотов B.M. Химическая модификация структуры натуральных антоциановых красителей / В.М. Болотов, Д.В. Рудаков // Известия ВУЗов : Пищевая технология. 1996. 一 № 6.

101. А.с. № 1535517 А1 СССР, МКИ5 А 23 L 1/272. Способ повышения стабильности природной окраски пастеризованного натурального гранатового сока при хранении / Г.К. Гафизов, Л.Г. Семочкина (СССР). № 1535517 ; заявл. 21.09.1987 ; опубл. 15.01.1990, Бюл. № 2. - 4 с. - C. $43-45$.

102. Friedman $M$. Inhibition of polyphenol oxidase by thiols in the absence and presence of potato tissue suspensions / M. Friedman, F. Bautisha // J.Agr. and Food Chera. - 1999. Vol. 47, № 1. - C. 56-60.

103. Hernander A. High-pressure and temperature effects on enzyme inactivation in tomato pure // Agr. and Food Chem. - 1998. - V.46, №1 - — P.266 - 270.

104. Gomes V.R. Degradation of polyphenol compounds in fruits and vegetables // J. Food Sci. - 1999. — Vol. 64. - P. 1116-1200. 